\title{
Trace Elements in Common Potatoes, Sweet Potatoes, Cassava, Yam and Taro
}

\author{
Petr Melnikov $^{1}$, Fernanda Zanoni Cônsolo ${ }^{2}$, Lourdes Zélia Zanoni ${ }^{1}$, \\ Anderson Fernandes da Silva ${ }^{1}$, José Rimoli, Valter Aragão do Nascimento ${ }^{1}$ * \\ ${ }^{1}$ School of Medicine, Federal University of Mato Grosso do Sul, Campo Grande, MS, Brazil \\ ${ }^{2}$ Department of Nutrition, Federal University of Mato Grosso do Sul, Campo Grande, MS, Brazil \\ ${ }^{3}$ School of Biology, Federal University of Mato Grosso do Sul, MS, Brazil
}

\begin{abstract}
The paper reports on the results of a survey of trace elements in common potatoes, sweet potatoes, cassava, yam and taro. The levels of aluminum, chromium, manganese, nickel, cobalt, molybdenum and cadmium in common potatoes, sweet potatoes, cassava, yam and taro consumed in Mato Grosso do Sul state, Brazil were evaluated. The concentrations were measured using a Inductively Coupled Plasma Optical Emission Spectrometry (ICP-OES, iCap 6000 ${ }^{\circledR}$ - Thermo Scientific, USA). It was shown that the levels of biometals in tubers, with the exception of aluminum and chromium, vary in a broad range, but do not exceed the limits established by the Brazilian and International legislation when available. No major concerns were identified for the health of consumers. The concentrations of aluminum in all tubers (1.53 - $2.9 \mathrm{mg} / \mathrm{kg})$ and chromium in taro $(0.41 \mathrm{mg} / \mathrm{kg})$ are higher, possibly reflecting the local soil characteristics or contamination and needing geochemical information.
\end{abstract}

Keywords: Common potatoes, Sweet potatoes, Cassava, Yam; Taro; Trace elements.

\section{INTRODUCTION}

The mineral content of foods is being increasingly monitored in tropical countries. The legislation is stricter in those regions of Latin America, Africa and Asia where the population consumes mainly locally grown food. Consequently, it requires the acquisition of large sets of fundamental data on the occurrence and distribution of a variety of bioelements in soils and food, and population exposure to them. The results of such investigations $[1,2]$ can in turn provide better understanding of the role of trace elements in life processes and support the establishment of guidelines and regulations. Dietary exposures to toxic metals like cadmium is falling as a result of measures taken to reduce contamination of the environment and food.

Meanwhile, vegetables, and tubers in particular, are the most widely consumed in the typical Brazilian diet. They provide physiological energy reserves, thus, their contribution to the population diet cannot be neglected. The plants have been known for a long time, primarily adopted from the Indian inhabitants of Latin America. Unfortunately, the data concerning rare and exotic trace elements are limited. This paper is part of our research into mineral components content in food samples [3, 4], reporting on aluminum, chromium, manganese, nickel, cobalt, cadmium and molybdenum in common potatoes, sweet potatoes, cassava, yam and taro consumed in Campo Grande, the capital of Mato Grosso do Sul state, Brazil.

\section{Material AND MeThOdS}

\subsection{Sample Collection}

The roots regularly consumed by the local inhabitants were analyzed. Good quality fresh samples of common potatoes, sweet potatoes, cassava, yam and taro were purchased from the wholesaler CEASA (Central Supply of Mato Grosso do Sul state). This company is linked to the Agricultural Development and Rural Extension Agency of Mato Grosso do Sul which provides vegetables to supermarkets, small markets and trade in general located in the capital and other cities in the state. 
Valter Aragão do Nascimento et.al

Such centralized distribution ensures the homogeneity of samples and the randomization of their collection. The general characteristics of five common tubers are given in Table 1.

Table1. General characteristics of roots selected for analysis

\begin{tabular}{|l|l|l|}
\hline Common name & Botanic name & State of origin, Brazil \\
\hline Common potatoes & Solanum tuberosum & Paraná \\
\hline Sweet potatoes & Ipomoea batatas & Mato Grosso do Sul \\
\hline Cassava & Manihot esculenta Crantz & Mato Grosso do Sul \\
\hline Yam & Dioscorea ssp & São Paulo \\
\hline Taro & Colocasia esculenta & São Paulo \\
\hline
\end{tabular}

\subsection{Analysis}

Each tuber was washed thoroughly with double distilled water, peeled with a plastic peeler and washed again, this time with ultrapure water (Milli-Q, Millipore, Bedford, USA). To determine the humidity, the samples were first grated, and after recording the wet mass ( $c a 2 \mathrm{~g}$ of the edible part of each vegetable) the matter was dried in an oven at the temperature $65{ }^{\circ} \mathrm{C}$ until attaining constant weight. Thence the oven was maintained at $105^{\circ} \mathrm{C}$ for 72 hours, according to published analytical technique [5]. These samples were accurately weighed on the microanalytical balance and processed with a mixture of $5 \mathrm{ml}$ of nitric acid $(65 \%$, Merck) and $3 \mathrm{ml}$ of hydrogen peroxide (35\%, Merck Millipore) in the microwave digestion system Speedwave ${ }^{\circledR}$, Berghof, Germany. The digestion was carried out according to the program presented in Table 2. After that, the solutions were cooled down to room temperature, diluted with ultrapure water to a final volume of $100 \mathrm{ml}$ and analyzed.

Table2. Parameters of sample digestion*)

\begin{tabular}{|l|l|l|l|l|l|}
\hline Step & Temperature $\left({ }^{\circ} \mathrm{C}\right)$ & Pressure $(\mathrm{bar})$ & Stop $(\mathrm{min})$ & Time $(\mathrm{min})$ & Energy $(\%)$ \\
\hline 1 & 145 & 30 & 2 & 10 & 80 \\
\hline 2 & 190 & 35 & 5 & 15 & 90 \\
\hline 3 & 50 & 25 & 1 & 10 & 0 \\
\hline
\end{tabular}

*) In accordance to manufacturer's scheme, from [6], with modifications.

The concentrations of aluminum, chromium, manganese, nickel, cobalt, cadmium and molybdenum were measured using an Inductively Coupled Plasma Optical Emission Spectrometry (ICP-OES, iCap $6000^{\circledR}$ - Thermo Scientific, USA). Working standard solutions used for the construction of calibrating curves were purchased from Aldrich. All glassware were of Pyrex ${ }^{\circledR}$ glass. All materials, plastic or glass, were previously immersed for $24 \mathrm{~h}$ in a solution of Extran 5\% (Merck), rinsed and immersed for at least $24 \mathrm{~h}$ in 10\% nitric acid (Merck) solution for decontamination from any metal residue. Then they were washed with ultrapure water and dried at $40{ }^{\circ} \mathrm{C}$ prior to analysis. The measurements were run in duplicates.

\section{RESUlts AND DisCUSSION}

The moisture content of the samples, with the exception of taro was similar to the averages previously published in Brazil [4], thus reflecting stable storage conditions (Table 3).

Table3. Moisture content of tubers studied (\% wet weight)

\begin{tabular}{|l|l|l|}
\hline Tubercular roots & Present work & Brazilian average \\
\hline Commom potato & 86.1 & 82.9 \\
\hline Sweet potato & 73 & 69.5 \\
\hline Cassava & 59.0 & 61.8 \\
\hline Yam & 67.4 & 73.7 \\
\hline Taro & 86.2 & 73.3 \\
\hline
\end{tabular}

As for the chemical elements involved, they are considered in the order of increasing atomic masses and discussed separately for each root (Table 4).

The results are given in Table 4. The data are expressed as means of duplicate determinations \pm standard deviation. 
Trace Elements in Common Potatoes, Sweet Potatoes, Cassava, Yam and Taro

Table4. Trace elements concentrations ( $\mathrm{mg} / \mathrm{kg}$ of wet weight \pm standard deviation) in edible tuberous roots compared to Brazilian averages and other sources.

\begin{tabular}{|c|c|c|c|c|c|c|c|}
\hline $\begin{array}{l}\text { Roots/ } \\
\text { Elements }\end{array}$ & Aluminum & Chromium & Manganese & Nickel & Cobalt & Molybdenum & Cadmium \\
\hline \multicolumn{8}{|l|}{$\begin{array}{l}\text { Common } \\
\text { potato }\end{array}$} \\
\hline Our data & $1.99 \pm 0.0013$ & $0.03 \pm 0.0012$ & $0.96 \pm 0.002$ & $\begin{array}{l}0.01 \pm \\
0.0011\end{array}$ & $0.04 \pm 0.001$ & $0.03 \pm 0.001$ & $0.01 \pm 0.0011$ \\
\hline BTFC $\left.^{*}\right)$ & - & - & 0.1 & - & - & - & - \\
\hline $\begin{array}{l}\text { Other } \\
\text { sources }\end{array}$ & \begin{tabular}{|l|}
0.9 United \\
Kingdom [7]; \\
0.93 \\
Brazil/SP [8]
\end{tabular} & $\begin{array}{l}0.063 \\
\text { Greece [9]; } \\
0.034 \text { USA } \\
{[10]}\end{array}$ & \begin{tabular}{|l|}
1.43 France \\
{$[11] ;$} \\
1.4 Spain $[12]$ \\
\end{tabular} & $\begin{array}{l}\text { 0.007 France } \\
\text { [11]; 0.029 } \\
\text { Lybia [13]; } \\
0.034 \\
\text { Brazil/SP [8] }\end{array}$ & $\begin{array}{l}0.051 \text { USA } \\
{[10] ;} \\
0.064 \text { Lybia } \\
{[13]}\end{array}$ & $\begin{array}{l}0.418 \text { France } \\
{[11]}\end{array}$ & $\begin{array}{l}0.007 \text { Greece } \\
{[9]}\end{array}$ \\
\hline \multicolumn{8}{|l|}{$\begin{array}{l}\text { Sweet } \\
\text { potato }\end{array}$} \\
\hline Our data & $2.4 \pm 0.001$ & $0.04 \pm 0.0012$ & $4.18 \pm 0.001$ & $\begin{array}{l}0.26 \pm \\
0.001\end{array}$ & $\begin{array}{l}0.03 \pm \\
0.001\end{array}$ & $\begin{array}{l}0.02 \pm \\
0.0002\end{array}$ & $\begin{array}{l}0.04 \pm \\
0.0011\end{array}$ \\
\hline BTFC & - & - & 1.8 & - & - & - & - \\
\hline $\begin{array}{l}\text { Other } \\
\text { sources }\end{array}$ & $\begin{array}{l}1.01 \text { USA } \\
{[10]}\end{array}$ & $\begin{array}{l}\text { 0.034 Spain } \\
{[14]}\end{array}$ & $\begin{array}{l}\text { 2.71 Spain } \\
{[14]}\end{array}$ & $\begin{array}{l}\text { 0.056 Spain } \\
{[14]}\end{array}$ & - & - & $\begin{array}{l}\text { 0.001 Spain } \\
{[13] ; 0.09} \\
\text { China [ } 15]\end{array}$ \\
\hline \multicolumn{8}{|l|}{ Cassava } \\
\hline Our data & $1.53 \pm 0.001$ & $0.08 \pm 0.0012$ & $2.61 \pm 0.001$ & $\begin{array}{l}0.16 \pm \\
0.002\end{array}$ & $\begin{array}{l}0.03 \pm \\
0.0002\end{array}$ & $0.05 \pm 0.0001$ & $0.01 \pm 0.0011$ \\
\hline BTFC & - & - & 0.5 & - & - & - & - \\
\hline $\begin{array}{l}\text { Other } \\
\text { sources }\end{array}$ & & $\begin{array}{l}0.05 \\
\text { Brazil/SP } \\
{[8]}\end{array}$ & 3.84 USA [10] & $\begin{array}{l}0.25 \text { Nigeria } \\
{[16]}\end{array}$ & - & - & $\begin{array}{l}0.13 \text { Nigeria } \\
{[16]}\end{array}$ \\
\hline \multicolumn{8}{|l|}{ Yam } \\
\hline Our data & $1.95 \pm 0.002$ & $0.03 \pm 0.002$ & $0.12 \pm 0.001$ & $\begin{array}{l}0.01 \pm \\
0.001\end{array}$ & $\begin{array}{l}0.015 \pm \\
0.001\end{array}$ & $0.05 \pm 0.002$ & $\begin{array}{l}0.02 \pm \\
0.0011\end{array}$ \\
\hline BTFC & - & - & 0.1 & - & - & - & - \\
\hline $\begin{array}{l}\text { Other } \\
\text { sources }\end{array}$ & - & - & - & \begin{tabular}{|l|}
0.014 \\
Nigeria [15]
\end{tabular} & - & - & $\begin{array}{l}0.18 \text { Gana } \\
{[17]}\end{array}$ \\
\hline \multicolumn{8}{|l|}{ Taro } \\
\hline Our data & $2.9 \pm 0.001$ & $0.41 \pm 0.011$ & $2.26 \pm 0.002$ & \begin{tabular}{|l|}
$0.09 \pm$ \\
0.0011 \\
\end{tabular} & $\begin{array}{l}0.04 \pm \\
0.0002\end{array}$ & $0.22 \pm 0.0003$ & $0.12 \pm 0.0011$ \\
\hline BTFC & - & - & 0.15 & - & - & - & - \\
\hline $\begin{array}{l}\text { Other } \\
\text { sources }\end{array}$ & - & $\begin{array}{l}\text { 0.044 Spain } \\
{[14]}\end{array}$ & $\begin{array}{l}\text { 2.63Brazil/MS } \\
{[18]}\end{array}$ & $\begin{array}{l}\text { 0.021 Spain } \\
{[14]}\end{array}$ & - & - & $\begin{array}{l}0.35 \text { China } \\
{[15]}\end{array}$ \\
\hline
\end{tabular}

*) Brazilian Table of Food Composition [19].

The only known published values for aluminum range from $0.9 \mathrm{mg} / \mathrm{kg}$ (common potato) to 1.01 $\mathrm{mg} / \mathrm{kg}$ (sweet potato). In this work the aluminum content of all analyzed roots was in the range 1.53 to $2.9 \mathrm{mg} / \mathrm{kg}$. It was assumed elsewhere [3] that in the case of fruit juices excessive aluminum could have been leached from the foil used for the packages. Actually it is evident that for the tubers this explanation cannot be valid, so we deal with an endogenously bonded biometal and not a contaminant. Thus further investigations seem to be required to correlate the concentration of this metal with the soil characteristics of the various growing locations.

Despite the presence of tanning industry present in Mato Grosso do Sul the chromium levels for the roots studied were ranged from 0.03 to $0.06 \mathrm{mg} / \mathrm{kg}$ with the exception of taro which contained 0.41 $\mathrm{mg} / \mathrm{kg}$. The current Brazilian legislation allows the maximum level of $0.1 \mathrm{mg} / \mathrm{kg}$ [20]. The available values published so far are from not detectable to $0.044 \mathrm{mg} / \mathrm{kg}$ in Spain. They are of a similar order for common potato, sweet potato, cassava and yam.

The manganese contents observed in the present study for the roots vary in a broad range, from 0.12 $\mathrm{mg} / \mathrm{kg}$ (yam) to $4.18 \mathrm{mg} / \mathrm{kg}$ (sweet potato), similar to reported manganese concentrations ranging from $0.1 \mathrm{mg} / \mathrm{kg}$ (common potato) to $3.84 \mathrm{mg} / \mathrm{kg}$ (cassava). 
The nickel concentrations for all of the roots studied ranged from $0.01 \mathrm{mg} / \mathrm{kg}$ (yam) to $0.26 \mathrm{mg} / \mathrm{kg}$ (sweet potato). They are within reasonable interval $0.014-0.25 \mathrm{mg} / \mathrm{kg}$ reported so far, which actually may be narrower since the maximum values 0.26 and $0.25 \mathrm{mg} / \mathrm{kg}$ have been observed only for sweet potato in Mato Grosso do Sul and Nigeria, respectively. Even so, the local legislation allows the maximum concentration of $30 \mathrm{mg} / \mathrm{kg}$ for this element [20].

As for the cobalt content, its concentrations in the present study were also low: $0.01-0.04 \mathrm{mg} / \mathrm{kg}$. They are lower than $0.051 \mathrm{mg} / \mathrm{kg}$ for common potato in the United States, but no published data are available for sweet potato, cassava, yam and taro.

The levels of toxic metal cadmium in all samples are acceptable: $0.01-0.04 \mathrm{mg} / \mathrm{kg}$ for common potato, sweet potato, cassava and yam, and $0.12 \mathrm{mg} / \mathrm{kg}$ for taro. The latter concentration is very close to the value of $0.10 \mathrm{mg} / \mathrm{kg}$ established as a maximum for the tubers by the current Brazilian legislation [21].

The data on molybdenum concentrations in the roots analyzed are missing in literature, with the exception of the French common potato $(0.418 \mathrm{mg} / \mathrm{kg})$. In our study, the levels of this element were low, $0.004-0.01 \mathrm{mg} / \mathrm{kg}$. It is not unusual since direct evidence for active plant uptake are lacking.

The present research was not intended to evaluate the nutritional capacity of tubers consumed in Brazil. No major concerns were identified for the heath of consumers. The data obtained here for biometal levels shows exclusively the population exposure to these minerals, concretely in Mato Grosso do Sul state, no assumptions made as to their real absorption or bioavailability.

\section{Conclusions}

- The levels of biometals in tubers, with the exception of aluminum and chromium, vary in a broad range, but do not exceed the limits established by the Brazilian and International legislation when available.

- The concentrations of aluminum in all tubers $(1.53-2.9 \mathrm{mg} / \mathrm{kg})$ and chromium in taro $(0.41$ $\mathrm{mg} / \mathrm{kg}$ ) are high, possibly reflecting the local soil characteristics or contamination and needing geochemical information.

- The concentrations of toxic metal cadmium do not exceed those established by the Brazilian legislation.

\section{ACKNOWLEDGMENTS}

The authors are indebted to FUNDECT (Brazilian agency) for financial support, grant 00720136.

\section{REFERENCES}

[1] McCance and Widdowson's The Composition of Foods, Sixth summary edition. Food Standards Agency. Cambridge: Royal Society of Chemistry. (2002).

[2] Rose M, Baxter M, Brereton N, Baskaran C. Dietary exposure to metals and other elements in the 2006 UK Total Diet Study and some trends over the last 30 years.Food Addit Contam Part A Chem Anal Control Expo Risk Assess. 2010; 27(10):1380-404

[3] Bragança V.L.C., Melnikov P., Zanoni L.Z. Trace elements in fruit juices. Biological Trace Element Research, Biol Trace Elem Res. 2012; 146, 256-261.

[4] Bragança V.L.C.; Melnikov P.; Zanoni L.Z. Trace elements in different brands of yerba mate tea. Biol Trace Elem Res. 2011; 144, 1197-1204.

[5] Zenebon, O., Pascuet, N.S., Tigela, P. Instituto Adolfo Lutz [São Paulo]. Procedimentos e determinações gerais. In: Métodos físico-químicos para análise de alimentos, 4th ed. Instituto Adolfo Lutz, São Paulo. (2008).

[6] Kotz L., Kaiser G.P., Tschopel G., Tolg Z. Theory of sample preparation using acid digestion, pressure digestion and microwave digestion [microwave decomposition]. Analytical Chemistry, 1972; 260, 207-209.

[7] U.S. department of health and human services Toxicological profile for aluminum, Public Health Service Agency for Toxic Substances and Disease Registry., Agency for Toxic Substances and Disease Registry Atlanta, Georgia. 2008. 
[8] Salazar R.F.S., Afonso S.S., Santos D.G., Oishi S.S., Izário F.H.J. Determinação de oligoelementos $[\mathrm{Cu}, \mathrm{Fe}, \mathrm{Zn}]$ e contaminantes inorgânicos $[\mathrm{Al}, \mathrm{Cd}, \mathrm{Ni}, \mathrm{Pb}]$ em hortaliças consumidas na cidade de Lorena. In: X Encontro Latino Americano de Iniciação Científica e VI Encontro Latino Americano de Pós-Graduação - Universidade do Vale do Paraíba. Instituto de Pesquisa e Desenvolvimento. Revista Univap, 2006; 13,34-37.

[9] Kirkillis C.G., Pasias Miniadis-Meimaroglou S.J.N., Thomaidis N.S., Zabetakis I. Concentration levels of trace elements in carrots, onions, and potatoes cultivated in Asopos region, central Greece. Anal Lett, 2012; 45, 553-8.

[10] Montagnac J.A., Davis C.R., Tanumihardjo S.A. Nutritional value of cassava for use as a staple food and recent advances for improvement. Comprehensive Reviews Food Science and Food Safety. 2009; 8, 181-194.

[11] Juvé V., Portelli R., Boueri M., Baudelet M., Yu J. Space-resolved analysis of trace elements in fresh vegetables using ultraviolet nanosencond laser-induced breakdown spectroscopy. Spectrochim Acta B. 2008; 63, 1047-1053.

[12] Peña R.M., García S., Iglesias R., Barro S., Herrero C. Authentication of Galician [NW Spain] quality brand potatoes using metal analysis. Classical pattern recognition techniques versus a new vector quantization-based classification procedure. Analyst, 2001; 126, 2186-2193.

[13] Elbagermi M.A., Edwards H.G.M., Alajtal A.I. Monitoring of heavy metal content in fruits and vegetables collected from production and market sites in the Misurata area of Lybia. ISRN Analytical Chemistry, 2012; 1-5.

[14] Luis-González G., Rubio C., Gutiérrez A., González-Weller D., Revert C., Hardisson A. Essential and toxic metals in taros [Colocasia esculenta] cultivated in the Canary Islands [Spain]: evaluation of content and estimate of daily intake. Environ Monit Assess. 2014; 187, 4138.

[15] Zhuang P., Mcbride M.B., Xia H., Li N., Li Z. Health risk from heavy metals via consumption of food crops in the vicinity of Dabaoshan mine, South China. Sci Total Environ. 2009; 407, 1551-1561.

[16] Shettima, B.G., Kolo, B.G., Ngala, A.L., Kajams, A.M. Analysis of Elemental and Organic Compound Composition of Cassava Tubers in Nigeria. J Agricul Veter Science. 2011; 3, 39-43.

[17] Essumang D.K., Dodoo D.K., Obiri S., Yaney J.Y. Arsenic, Cadmium, and Mercury in Cocoyam [Xanthosoma sagititolium] and watercocoyam [Colocasia esculenta] in Tarkwa a mining community. B Environ Contam Tox. 2007; 79, 377-379.

[18] Filho M.M.R., Ramos M.I.L., Hiane P.A. Avaliação química do inhame [Colocasia esculenta l. Schott] cultivado em solo alagadiço na região pantaneira de Mato Grosso. Centro de Pesquisa e Processamento de Alimentos. 1997; 15, 175-186.

[19] BRASIL. Tabela Brasileira de Composição de Alimentos. 4th ed. Campinas: NEPA-UNICAMP. 2011;30-35.

[20] Tabela brasileira de composição de alimentos [2011] 4 ed. NEPA-UNICAMP, Campinas. pp 3035ecreto $\mathrm{n}^{\circ} 55871$, de 26 de março de 1965. D.O.U. - Diário Oficial

[21] da União; Poder Executivo, de 09 de abril de 1965

[22] [A] Decreto n ${ }^{\circ} 55871$, de 26 de março de 1965. D.O.U. - Diário Oficial

[23] da União; Poder Executivo, de 09 de abril de 1965.

[24] BRASIL. Decreto n. 55871, de 26 de Março de 1965. D.O.U. - Diário Oficial da União, Poder Executivo, de 09 de abril de 1965. Modifica o Decreto n ${ }^{\circ} 50.040$, de 24 de janeiro de 1961, referente a normas reguladoras do emprego de aditivos para alimentos, alterado pelo Decreto $\mathrm{n}^{\circ}$ 691, de 13 de março de 1962.

[25] BRASIL. Resolução (RDC) no 42, de 29 de Agosto de 2013. D.O.U. - Diário Oficial da União, Poder Executivo, de 30 de agosto de 2013. Diretoria colegiada da Agência Nacional de Vigilância Sanitária. Regulamento técnico MERCOSUL sobre limites máximos de contaminantes inorgânicos em alimentos. 